\title{
Conjugated linoleic acids regulate triacylglycerol and cholesterol concentrations in macrophages/foam cells by the modulation of CD36 expression
}

\author{
Ewa Stachowska1凶${ }^{\bowtie}$, Magdalena Baskiewicz², Mariola Marchlewicz³, Katarzyna Czupryńska \\ Mariusz Kaczmarczyk4, Barbara Wiszniewska³, Bogusław Machaliński² and Dariusz Chlubek ${ }^{5}$
}

\begin{abstract}
Atherosclerosis is an inflammatory disease characterised by the accumulation of lipids and their metabolites in the artery wall. During inflammation circulating LDL are taken up by macrophages through two major scavenger receptors: CD36 and scavenger receptor A (SRA). Fatty acids that are common in food, e.g. linoleic acid and $n-3$ unsaturated fatty acids can modulate expression of CD36 on the macrophage surface. Conjugated linoleic acid isomers (CLA) that originate from the human diet, have demonstrated antiatherogenic properties in several experiments. Animal study evidenced that CLA could induce resolution of plaque by activation of peroxisome proliferator activated receptors and down-regulation of pro-inflammatory genes. Less unequivocal results were obtained in human studies (on the CLA effects on the inflammatory process). Therefore in this study we investigated the influence of CLA on CD36 expression and lipid accumulation in human macrophages. Macrophages were incubated with $30 \mu \mathrm{M}$ cis-9,trans-11 CLA, trans10,cis-12 CLA or linoleic acid for $48 \mathrm{~h}$. After that, expression of CD36 as well as accumulation of lipids were measured by flow cytometry, microscopy and a spectroscopic method. We demonstrate that both cis-9,trans-11 C 18:2 CLA and linoleic acid slightly elevated expression of CD36, whereas second isomer - trans-10,cis-12 CLA - did not. Nevertheless, only trans-10,cis-12 CLA triggered delipidation of macrophages, that is decreased triacylglycerols concentration. Also in human adipocytes, trans-10,cis-12 CLA causes cell delipidation by reduction of PPAR receptor expression. We propose a similar mechanism for human macrophages/foam cells.
\end{abstract}

Keywords: CLA, CD36, macrophages, foam cells, triacylglycerols, cholesterol, PPAR

Received: 28 October, 2009; revised: 22 April, 2010; accepted: 21 May, 2010; available on-line: 09 June, 2010

\section{INTRODUCTION}

Conjugated linoleic acids (CLA) are an extraordinary category of stereoisomers of linoleic acid (Park et al., 2002; Badigna et al., 2006). CLA isomers - cis-9,trans-11 C18:2 and trans-10,cis-12 C18:2 are common in the diet (from food or popular dietary supplements) (AbuGhazaleh et al., 2003). Animal studies have evidenced antiatherosclerotic, anticancer and antidiabetic properties of CLA (Park et al., 2002; Evans et al., 2001a; 2001b). CLA inhibits the atherosclerotic process by reducing inflam- mation, and the concentration of triacylglycerols and total and LDL cholesterol (Evans et al., 2001a; 2001b; Park et al., 2002). Less unequivocal results were obtained in studies on the effects of CLA in humans (Lee et al., 1994; Lee et al., 2005; 2006a; 2006b; Whigham et al., 2001).

Atherosclerosis is a progressive chronic inflammatory disease characterised by deposition of triacylglycerols, cholesterol, calcium and other substances within the artery wall. The accumulation of lipids and their metabolites can induce chronic inflammation by promoting macrophage infiltration and activation (Prieur et al., 2009). During inflammatory disorders, macrophages accumulate within the arterial neointima and become a major contributor of the atherosclerotic plaque (Rahman et al., 2006). The first stage of this process is the appearance of dysfunctional endothelial cells whose activated adhesion molecules and expressed chemokines recruit circulating monocytes and a subpopulation of lymphocytes (CD4/CD8) into the intima (Collot-Texiera et al., 2007).

In this pathological setting, a high level of LDL may accumulate in the arterial wall, where it undergoes modifcation by macrophages (Prieur et al., 2009). The modification of LDL increases lipoprotein uptake by macrophages through the overexpression of two major scavenger receptors: CD36 and scavenger receptor A (SRA) (Prieur et al., 2009). CD36 is a multi-ligand scavenger receptor present on the surface of a number of cells such as monocytes/macrophages, platelets, and endothelial cells. Monocyte/macrophage CD36 has been shown to play a key role in the development of atherosclerotic lesions by its capacity to bind and endocytose oxidised low density lipoproteins (ox-LDL), and its implication in the formation of foam cells (Collot-Texiera et al., 2007). Expression of CD36 in macrophages is controlled by peroxisome proliferator activated receptors type $\gamma$ (PPAR $\gamma$ ) (Toomey et al., 2003). PPAR $\gamma$ also plays a role in maintaining the balance between lipid influx and efflux in macrophages. Although PPAR $\gamma$ activation induces the fatty acid transporter CD36, recent work shows that this effect is not associated with foam cell formation. CD36 can promote lipid efflux by inducing ATP binding

e-mail: ewast@sci.pam.szczecin.pl

Abbreviations: CD36, scavenger receptor A; CLA, conjugated linoleic acid; FC, foam cells; LA, linoleic acid; ox-LDL, oxidated low density lipoprotein; PPAR, peroxisome proliferator activated receptors; SRA, scavenger receptor $A$ 
cassette protein A1 (ABCA1) (Taketa et al., 2008). Fatty acids and their derivatives 9-HODE, 13 -HODE, can modulate CD36 gene expression in human macrophages (Collot-Texiera et al., 2007; Prieur et al., 2009). n-3 fatty acids of fish oil origin: docosahexaenoic (DHA) and eicosapentaenoic (EPA) that are considered as preventive factor against inflammatory diseases reduced the expression of both mRNA and protein of CD36 in monocytic cells (Pietsch et al., 1995; Collot-Texiera et al., 2007). Linoleic acid (cis-9,cis-12 C 18:2) was reported to increase CD36 expression in human macrophages (Vallve et al., 2002).

Previously we demonstrated a pro-atherogenic activity of CLA (Stachowska et al., 2007; 2008). Since CD36 has been implicated in atherosclerotic plaque development, we decided to investigate the influence of CLA on the expression of CD36 and concentrations of triacylglycerols and cholesterol in human macrophages/foam cells.

\section{MATERIALS AND METHODS}

Materials. Cell culture media and fetal bovine serum (FBS) were obtained from Gibco (UK). All other chemicals and reagents were purchased from Sigma Chemical Co. (St. Louis, MO, USA) or Sigma (Sigma-Aldrich, Poland), unless stated otherwise. Isomers of CLA (+98\% pure) were purchased from Nu-CheK Prep (USA). CD36 antibody was purchased from BD Pharmingen (USA). Commercial kits for determination of triacylglycerols and total cholesterol were from Biolabo (France). GW 6471, a PPAR $\alpha$ antagonist, was obtained from Calbiochem (USA).

Cell culture and treatment. The human monocytic cells (THP-1) were purchased from American Type Culture Collection (ATCC, Rockville MD, USA) and cultured in RPMI 1640 medium supplemented with 10\% fatty acid free FBS, penicillin $(100 \mathrm{U} / \mathrm{ml})$ and streptomycin $(100 \mathrm{mg} / \mathrm{ml})$ at $37{ }^{\circ} \mathrm{C}$ in $5 \% \mathrm{CO}_{2}$. The cells were differentiated to macrophages by administration of phorbol myristate acetate (PMA).

THP-1 monocytes were seeded at a density of $2 \times 10^{6}$ cells/well in 6-well plates and incubated with $100 \mathrm{nM}$ PMA for 24h (Collot-Texiera et al., 2007). After incubation with PMA, adherent cells (macrophages) were washed three times with phosphate-buffered saline (PBS) and incubated with $30 \mu \mathrm{M}$ fatty acids (cis-9,trans-11 CLA, trans-10,cis-12 CLA or linoleic acid) for $48 \mathrm{~h}$ at $37^{\circ} \mathrm{C}$ as described in detail (Stachowska et al., 2007). Foam cells were obtained after additional macrophage incubation with ox-LDL $(50 \mu \mathrm{g} / \mathrm{ml})$ for $24 \mathrm{~h}$ at $37^{\circ} \mathrm{C}$. In some experiments, after incubation with fatty acids the cells were cultured for $24 \mathrm{~h}$ with cholesterol (ethanolic solution; 50 $\mu \mathrm{g} / \mathrm{ml})$.

Preparation of fatty acids. Both isomers of CLA were complexed to fatty acid-free $(>98 \%)$ bovine serum albumin (BSA) at a 4:1 molar ratio using as described in detail (Evans et al., 2001).

Preparation of ox-LDL (induced by $\mathrm{Cu}^{2+}$ ). LDL was isolated from blood plasma obtained from patients with a normal lipid profile. The plasma was centrifugation $\left(112000 \times g\right.$ for $24 \mathrm{~h}$ at $\left.16^{\circ} \mathrm{C}\right)$ in a Beckman L8-80M ultracentrifuge fitted with a Ti 80 rotor (Baillie et al., 1996). The disc containing LDL obtained after centrifuging was transferred to an Econo-Pac 10 DG Sephadex G-25 column (Pharmacia) to remove impurities. The obtained LDL suspension was kept with EDTA $(1 \mathrm{mg} / \mathrm{ml})$ added in nitrogen atmosphere at $4{ }^{\circ} \mathrm{C}$ until the time of oxidation (not longer than one week). LDL suspension $(1 \mathrm{ml})$ was transferred to an Econo-Pac 10 DG column washed with PBS and the filtrate was collected. After each LDL portion, the column was washed with $5 \mathrm{ml}$ of PBS and then the next LDL portion was applied. Protein concentration in the filtrate was measured with the Bradford reagent; the filtrate was diluted with PBS to $100 \mu \mathrm{g}$ of protein $/ \mathrm{ml}, \mathrm{Cu} \mathrm{SO}_{4}$ was added $(10 \mu \mathrm{M})$ and the total content was incubated for $6 \mathrm{~h}$ at $37^{\circ} \mathrm{C}$. Oxidation was inhibited at $4^{\circ} \mathrm{C}$ by adding EDTA $(200 \mu \mathrm{M})$ and butylated hydroxytoluene, BHT $(40 \mu \mathrm{M})$. The total content was dialysed. After dialysis, $200 \mu \mathrm{l}$ of the suspension was taken for measurement of protein and thiobarbituric acid reactive substances (TBARS) content (Havel et al., 1955). The ox-LDL received was frozen at $-80^{\circ} \mathrm{C}$ for not more than 3 months. A freezing-unfreezing cycle was avoided. ox-LDLs were added to macrophages to reach LDL final protein concentration in the cultivation well of 50 $\mu \mathrm{g} / \mathrm{ml}$.

Expression of CD36 measurement. The percentage of CD36+ cells was assessed by flow cytometry (FACScan) using CellQuest software. CD36+ cells were washed with ice-cold PBS, fixed with 4\% paraformaldehyde and incubated with fluorochrome-conjugated monoclonal PE CD36 antibody for $30 \mathrm{~min}$. Mouse IgM was used as an isotype control antibody (Becton Dickinson, Oxford, UK). Macrophages cultured without BSA and fatty acids were used in this study as a negative control.

Measurement of total cholesterol and triacylglycerol content in macrophages/foam cells. THP-1derived macrophages $\left(2.5 \times 10^{6}\right.$ cells/well $)$ were cultured with $30 \mu \mathrm{M}$ fatty acids and with cholesterol $(50 \mu \mathrm{g} / \mathrm{ml})$. Incubation at $37^{\circ} \mathrm{C}$ lasted for $48 \mathrm{~h}$. After that, in macrophages which were differentiated to foam cells, incubation with ox-LDL $\left(50 \mu \mathrm{g} / \mathrm{ml}\right.$ for $24 \mathrm{~h}$ at $\left.37^{\circ} \mathrm{C}\right)$ was additionally conducted. After incubation the cells were scraped, washed three times with PBS $(10 \mathrm{~min}, 850 \times \mathrm{g})$, and $1 \mathrm{ml}$ isopropyl alcohol was added, the suspension was sonicated for $30 \mathrm{~s}$ and used for lipid determinations. Triacylglycerols and total cholesterol were determined by an enzymatic method using a commercial kit (Biolabo, France) with spectroscopic reading (Perkin Elmer Lambda 40) and referred to the protein concentration in the cells. Protein concentration was estimated by the Bradford method with commercial reagents (Sigma-Aldrich).

Oil Red O (ORO) staining and confocal microscopy. Macrophages $\left(2.5 \times 10^{6}\right.$ cells $/$ well $)$ were cultured with $30 \mu \mathrm{M}$ fatty acids for $48 \mathrm{~h}\left(37^{\circ} \mathrm{C}\right)$ as described above. In macrophages after incubation with fatty acids, stimulation with ox-LDL $(50 \mu \mathrm{g} / \mathrm{ml}$ for $24 \mathrm{~h})$ was conducted. After incubation with fatty acids, cells were washed three times with PBS to remove suspended apoptotic cells. The phagocytic cells were fixed with $10 \%$ formalin for $40 \mathrm{~min}$. After a wash with PBS, the cells were stained with saturated ORO solution in isopropanol/water $(3: 2, \mathrm{v} / \mathrm{v})$ for 15 min. Then, the cells were washed with $70 \%$ ethanol for $5 \mathrm{~s}$ to remove background staining. Finally, the cells were rinsed in tap water, counterstained with Harris hematoxylin $(10 \mathrm{~s})$, and mounted in glycerol/PBS $(9: 1, \mathrm{v} / \mathrm{v})$ for observation. Cells were viewed in situ in $35 \mathrm{~mm}$ diameter tissue culture plates under a bright-field using an Olympus IMT-2 inverted phase-contrast microscope with $\times 100$ objective (Cynshi et al., 1994).

Confocal microscopy is a powerful imaging technique for this task, due to its capability to perform high resolution imaging and optical sectioning in both reflectance and fluorescence modes. Macrophages $\left(2.5 \times 10^{6}\right.$ cells/well) were cultured with $30 \mu \mathrm{M}$ fatty acids for $48 \mathrm{~h}$ 


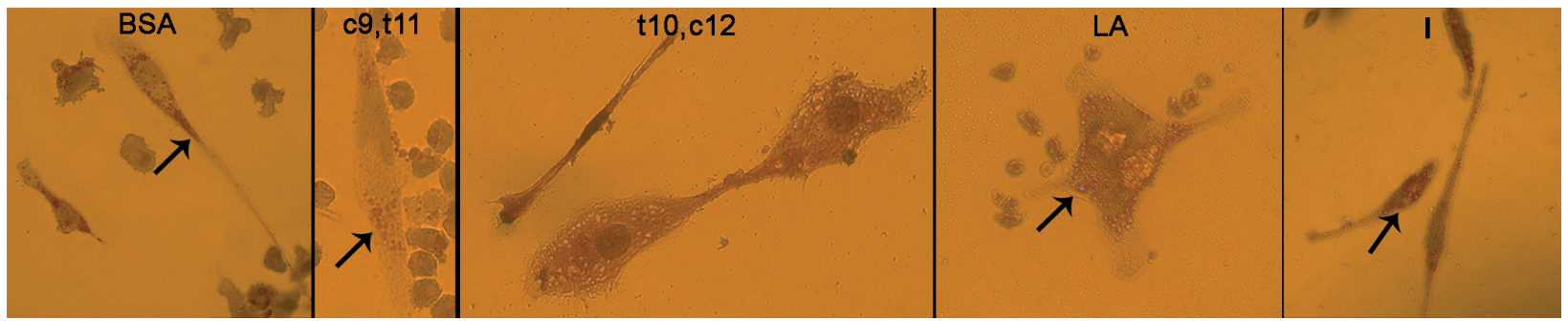

Figure 1. Cell morphology and lipid droplets in macrophages

Macrophages were treated with BSA (a vehicle control), $30 \mu \mathrm{mol} / \mathrm{l}$ cis-9,trans-11-C 18:2, trans-10,cis-12-C 18:2, or linoleic acid for 2 days. Cells were harvested, fixed with $4 \%$ paraformaldehyde and stained with Oil Red O. Then cells were lightly counterstained with hematoxylin. Intracellular lipid droplets were stained red (100x microscopic field). Droplets are marked by black arrows. Cells cultured with BSA are labeled BSA; with cis-9,trans-11-C 18:2 - c9,t11; with trans-10,cis-12 — t10,c12; with linoleic acid — LA; with GW 6471 — I.

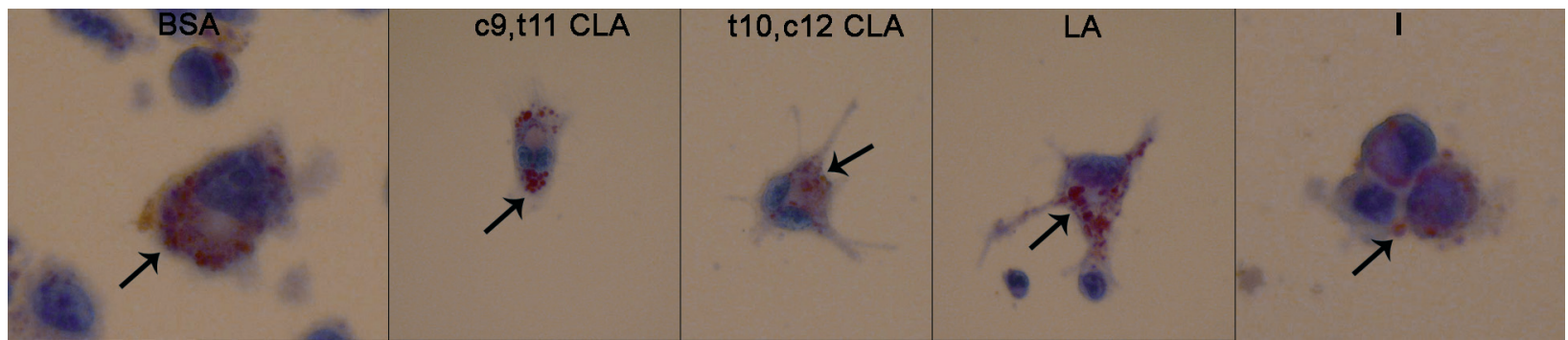

Figure 2. Cell morphology and lipid droplets in foam cells

Foam cells were treated with BSA (a vehicle control), $30 \mu \mathrm{mol} / \mathrm{l}$ cis-9,trans-11-C 18:2, trans-10,cis-12-C 18:2, or linoleic acid for 2 days. Foam cells were obtained after additional macrophage incubation with ox-LDL $(50 \mu \mathrm{g} / \mathrm{ml})$ for $24 \mathrm{~h}$ at $37^{\circ}$ C. Cells were then harvested, fixed with $4 \%$ paraformaldehyde and with Oil Red O. Then cells were lightly counterstained with hematoxylin. Intracellular lipid droplets were stained in red (100x microscopic field). Droplets are marked by black arrows. Cells cultured with BSA are labeled BSA; with cis9,trans-11-C 18:2 - c9,t11; with trans-10,cis-12 - t10,c12; with linoleic acid - LA; with GW 6471 - I.

$\left(37^{\circ} \mathrm{C}\right)$, and then with cholesterol $(50 \mu \mathrm{g} / \mathrm{ml}) / 24 \mathrm{~h}$. After that, cells were viewed with an Olympus FV500 laser scanning confocal microscope.

Statistical analysis. All results are expressed as mean \pm standard deviation. As the distribution in most cases deviated from normal (Shapiro-Wilk test), non-parametric tests were used. For related samples, significance was first checked with Friedmann's ANOVA, then significant results were subjected to the Wilcoxon matched-pair test. The software used was Statistica 6.1, Statsoft (Poland). $P<0.05$ was considered significant.

\section{RESULTS}

\section{Trans-10,cis-12 CLA decreases lipid content and alters morphology of lipid droplets in macrophage and foam cells}

To investigate the isomer-specific regulation of macrophage/foam cell morphology (as well as triacylglycerol and cholesterol content) cells were treated with $30 \mu \mathrm{M}$ CLA isomers (trans-10, cis-12, or cis-9,trans-11) or linoleic acid as well as BSA (control) as described in Materials and Methods. Foam cells were obtained by additional incubation with ox-LDL $(50 \mu \mathrm{g} / \mathrm{ml})$ for additional 24 $\mathrm{h}$, at which the cell morphology and content of triacylglycerols and cholesterol were investigated. Macrophages treated with linoleic acid contained relatively large lipids droplets within each cell compared to control cells incubated with BSA (Fig. 1). Less pronounced accumulation of lipid droplets was observed in cells cultured with cis-9,trans-11 CLA - Fig. 1. Similar results were obtained for foam cells (Fig. 2).

In contrast, macrophages/foam cells cultured with trans-10,cis-12 CLA contained few lipid droplets (Figs. 1 and 2). Also the morphology of macrophages cultured with trans-10, cis-12 CLA isomer was different from that of macrophages cultured with the other fatty acids (Fig. 1). Treatment of the cells for 2 days with trans-10 cis-12 CLA, but not cis-9,trans-11 CLA or LA, signifi-

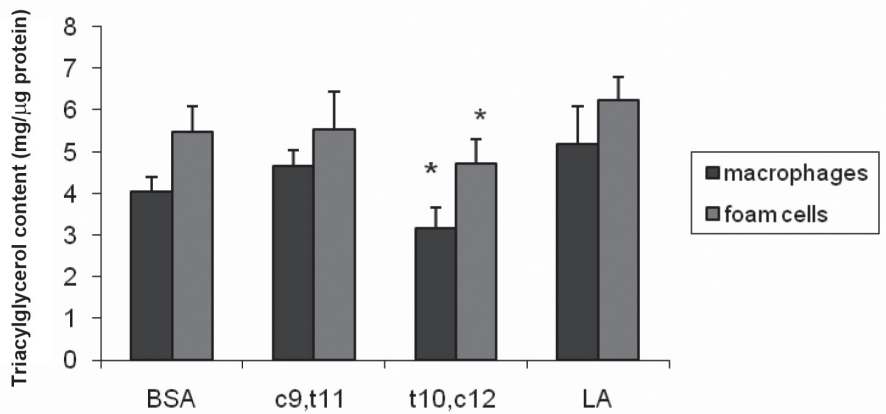

Treatments
Figure 3. Effect of CLA on concentration of triacylglycerol in macrophages

Cells were grown in differentiation medium containing BSA (a vehicle control), $30 \mu \mathrm{mol} / \mathrm{l}$ cis-9,trans-11-C 18:2, trans-10,cis-12-C $18: 2$ or linoleic acid for 2 days. Triglycerides concentration was determined spectrophotometrically. The data are expressed as mean $(\mathrm{mg} / \mathrm{mg}$ protein) \pm S.D. from ten separate experiments. Values with different letters are significantly different $(P<0.05)$. 


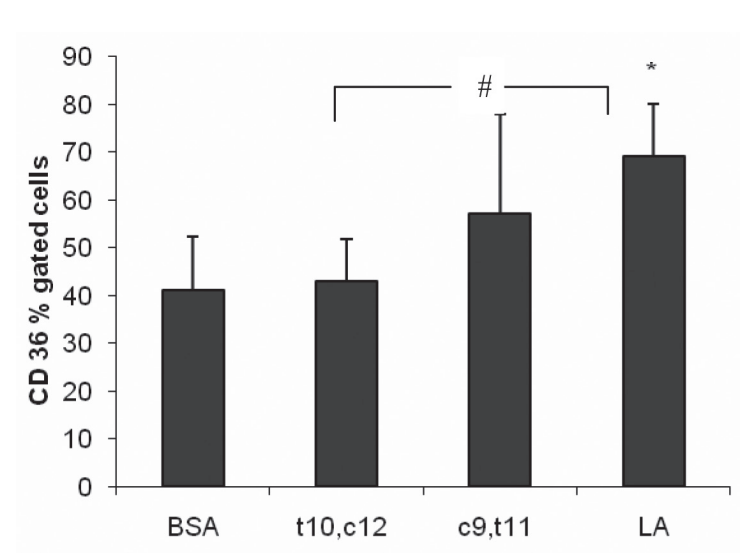

Figure 4. Effect of CLA on CD36 expression in THP-1 macrophages

Cells were grown in differentiation medium containing BSA (a vehicle control), $30 \mu \mathrm{mol} / \mathrm{l}$ cis-9,trans-11-C 18:2, trans-10,cis-12-C $18: 2$, or linoleic acid for 2 days, and with ox-LDL $(50 \mu \mathrm{g} / \mathrm{ml}, 24 \mathrm{~h})$. Results are expressed as percentage of CD 36 positive cells and given as mean \pm S.D. from eight separate experiments as described in Materials and Methods. *Compared to BSA; \#compared to linoleic acid. Values with different letters are significantly different $(P<0.05)$.

cantly reduced the triacylglycerol content in macrophages (Fig. 3) $(P<0.05, \mathrm{n}=10)$ as well as in foam cells $P<0.05, \mathrm{n}=10)$ (Fig. 3).

The inhibitor of PPAR $\alpha$, GW 6471, slightly raised the triacylglycerol content compared to BSA control in both macrophages (Fig. 1) and foam cells (Fig. 2).

\section{CD36 expression is decreased in macrophages cultured with trans-10,cis-12 CLA}

Studies on the expression of CD36 were conducted in macrophages obtained from THP-1 cells cultured for $48 \mathrm{~h}$ with fatty acids $(30 \mu \mathrm{M})$ and with ox-LDL for $24 \mathrm{~h}$. In these conditions CD36 is induced on the cell surface $(P<005, \mathrm{n}=8)$ - Fig. 4. Expression of CD36 was elevated in cells cultured with LA (compared to BSA, $P<0.05, \mathrm{n}=8)$, whereas in the presence of cis-9,trans-11 C 18:2 a strong tendency toward induction was seen. A slight increase of CD36 expression was observed in cells cultured with trans-10,cis-12 18:2 C (compared to BSA).

\section{CLAs do not change the cholesterol level in foam cells}

As shown in Figs. 5 and 6, cultivation of foam cells with the examined fatty acids did not significantly influ- ence the cholesterol content. Only a slight tendency to reduce the cholesterol content in cells cultivated with trans-10, cis-12 CLA (compared to BSA; Fig. 6) was observed.

\section{DISCUSSION}

In animals, CLA induced the resolution of atherosclerosis by negatively regulating the expression of pro-inflammatory genes and by activation of apoptosis in the atherosclerotic lesion (Tommey et al., 2003). We have previously demonstrated that CLA shows some proatherogenic activity in vitro: it stimulates reactive oxygen species (ROS) production and isoprostan PGF $2 \alpha$ synthesis, elevates phagocytosis and apoptosis in human monocytes/macrophages in vitro (Stachowska et al., 2007; 2008). Pro-atherosclerotic action of CD36 is associated with its participation in the uptake of ox-LDL from circulation (Teupser et al., 2008), in this study we characterised the isomer-specific effects of CLA on CD36 expression and lipid accumulation in macrophages. We demonstrated that linoleic acid (LA, n- 6 ) and cis-9,trans-11 CLA increased or tended to increase expression of CD36 (compared to the BSA control). We also noticed that high amount of the lipids (triacylglycerols and total cholesterol) accumulated in cells cultured with cis-9,trans-11 CLA. Our data suggest that both cis-9,trans-11 CLA and LA can up-regulated CD36 expression and lipid deposition in human macrophages/foam cells. Other authors who studied the effect of linoleic acid and other $n-6$ unsaturated fatty acids on CD36 expression showed that linoleic acid (as well as arachidonic acid) elevated the expression of CD36 in human monocytic cells (Pietsch et al., 1995). In contrast $n-3$ fatty acids eicosapentaenoic acid (EPA) and docahexaenoic acid (DHA) investigated in the same study, reduced both CD36 mRNA and protein (Pietsch et al., 1995). In contrast, Vallve and coworkers and others observed that LA, EPA, or DHA increased CD36 expression (mRNA and protein) in macrophages (Collot-Texiera et al., 2007; Vallve et al., 2002).

Opposite results were obtained in this study for cells cultured with trans-10, cis-12 CLA. This isomer repressed both CD36 expression and deposition of lipids in macrophages when compared with other treatments: cis-9,trans-11 CLA, or LA. (Fig. 4). Trans-10,cis-12 CLA has been shown earlier to alter in vitro lipid metabolism and specifically to decrease triacylglycerol accumulation in other cells, e.g. primary human adiopcytes. This CLA isomer inhibited fatty acid desaturation by decreasing the activity of desaturases and also by disturbing glu-

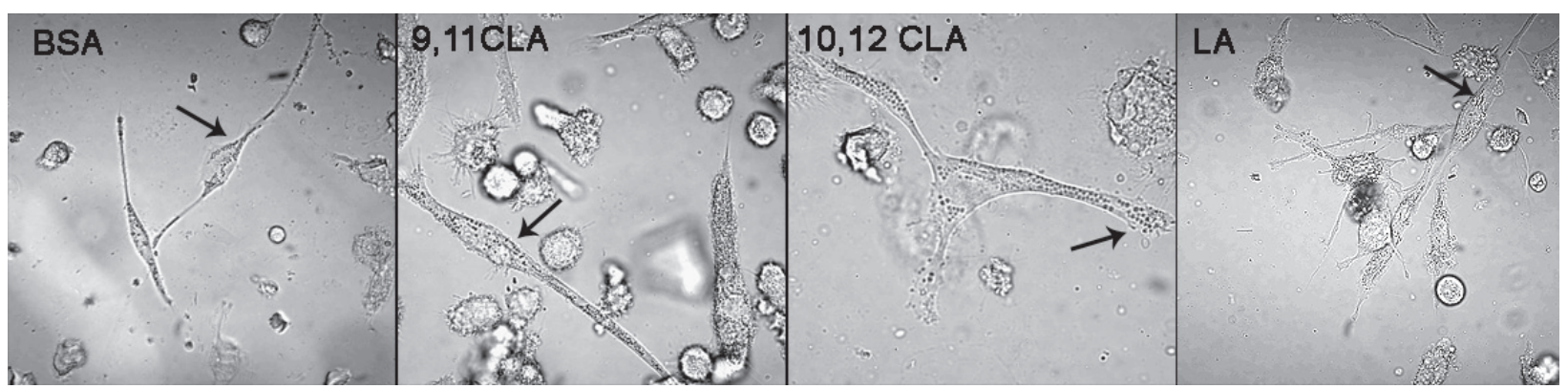

Figure 5. Cholesterol droplets in foam cells.

Macrophages were treated with BSA (a vehicle control), $30 \mu \mathrm{M}$ cis-9,trans-11 CLA (9, 11), trans-10,cis-12 CLA (10, 12), or linoleic acid (LA) for 2 days. Foam cells were obtained after additional incubation of macrophages with ox-LDL $(50 \mu \mathrm{g} / \mathrm{ml})$ for $24 \mathrm{~h}$ at $37^{\circ} \mathrm{C}$. Cells were then harvested and viewed with an Olympus FV500 laser scanning confocal microscope. Droplets of cholesterol are marked by black arrows. 


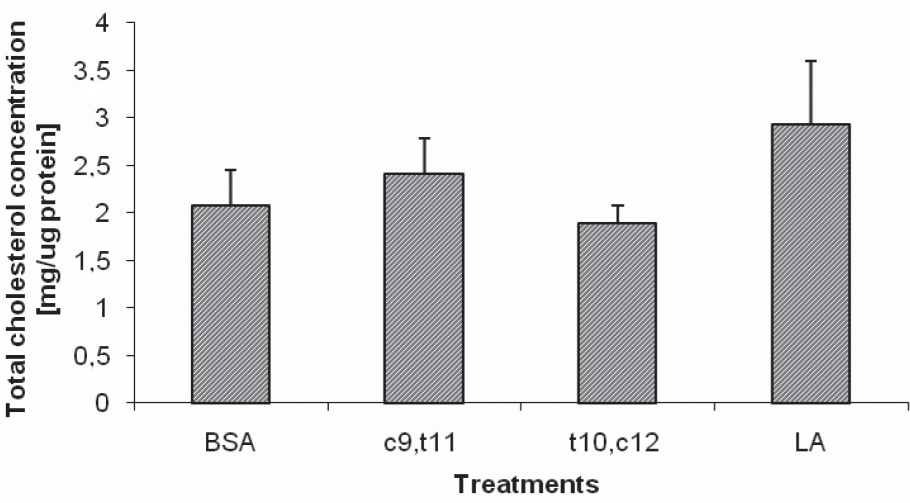

Figure 6. Effect of CLA on cholesterol concentration in foam cells

Cells were grown in medium containing BSA (a vehicle control), $30 \mu \mathrm{M}$ cis-9,trans-11 CLA, trans-10, cis-12 CLA, or linoleic acid for 2 days. Foam cells were obtained as described in Materials and Methods. Cholesterol concentration was determined spectrophotometrically. The data are expressed as mean $(\mathrm{mg} / \mathrm{mg}$ protein) \pm S.D. from ten separate experiments. Values with different letters are significantly different $(P<0.05)$. cose uptake (Brown et al., 2003). According to Brown and coworkers trans-10, cis-12 CLA leads to delipidation by down-regulation of the ativity of PPAR $\gamma$ receptor and several of its target genes. This phenomena may lead to insulin resistance, hyperglycemia, and hyperlipidemia. We suppose that a similar process may concern macrophages, where we noticed reduction of cholesterol and triacylglycerol content (Figs. 3 and 5). Also Ringseis et al. (2008) has shown that in mouse macrophages CLAs affect cholesterol efflux and reduce cholesterol accumulation. In the study of Ringseis et al. (20008) both cis9,trans-11 and trans-10,cis-12 CLA lowered cholesterol accumulation. This process consisted in stimulation of cholesterol efflux, and elevation of expression of genes CD36, ABCA1, LXRalpha, NPC-1, and NPC-2 (Ringseis et al., 2008). Cholesterol metabolism and lipid concentration in macrophages by are regulated PPAR receptors. Activators of PPAR are capable of reducing cholesterol accumulation through the activation of genes involved in cholesterol homeostasis (Ringseis et al., 2008) as well as in ox-LDL uptake (Nagy et al., 1989; Tontonoz et al., 1998; Kliewer et al., 1999). Mice that were fed a diet containing $0.5 \%$ CLA had an elevated expression of both $\operatorname{PPAR} \gamma$ and PPAR $\alpha$ in the aortas (Toomey et al., 2003). This coincided with the reduction of CD36 expression and elevation of apoptosis in the aorta (Toomey et al., 2003). This upregulation of CD36 by PPAR can be substantially enhanced by various ligands: linoleic acid (Kliewer et al., 1999; Nagy et al., 1989), ox-LDL, 15dPGJ2 ond other (Xie et al., 2009). We hypothesize that trans-10,cis-12 C 18:2 may antagonize activation of PPAR $\alpha$ and in this way reduce CD36 expression and ox-LDL transport to foam cells. When the inhibitor of PPAR $\alpha$ GW 6471 was added to macrophages the triacylglycerol content increased (Figs. 1 and 2).

In summary, we show that trans-10,cis-12 CLA induces macrophage delipidation in vitro by down regulation of PPAR, however, further investigations are required to see whether the same effect occurs in vivo.

\section{Acknowledgements}

Supported by grant No. 15 P0B 11723 from the State Committee for Scientific Research, Poland.

\section{REFERENCES}

AbuGhazaleh AA, Schingoethe DJ, Hippen AR, Kalscheur KF (2003) Conjugated linoleic acid and vaccenic acid in rumen, plasma, and milk of cows fed fish oil and fats differing in saturation of 18 carbon fatty acids. J Dairy Sci 86: 3648-3660.
Badinga L, Greene ES (2006) Physiological properties of conjugated linoleic acid and implications for human health. Nutr Clin Pract 21: 367-363.

Bailllie AGS, Coburn CT, Abumrad NA (1996) Reversible binding of long-chain fatty acids to purified FAT, the adipose CD36 homolog. J Membr Biol 153: 75-81.

Brown JM, Boysen MS, Jensen SS, Morrison RF, Storkson J, Lea-Currie R, Pariza M, Mandrup S, McIntosh MK (2003) Isomer specific regulation of metabolism and PPAR gamma signalling by CLA in human preadipocytes. J Lipid Res 44: 1287-1300.

Collot-Texiera S, Martin J, McDermott-Roe C, Poston R, McGregor JL (2007) CD36 and macrophages in atherosclerosis. Cariovasc Res 75: 468-477.

Cynshi O, Takashoma Y, Suzuki T, Kawabe Y, Ohba Y, Kodama T (1994) Characterization of aggregated low density lipoproteins induced by copper-catalyzed oxidation. J Atheroscler Thromb 1: 87-96.

Evans M, Geigerman C, Cook J, Curtis L, Kuebler B, McIntosh M (2001a) Conjugated linoleic acid suppresses triglyceride accumulation and induces apoptosis in 3T3-L1 preadipocytes. Lipids 36: 899-910.

Evans M, Park Y, Pariza M, Curtis L, Kuebler B, McIntosh M (2001b) Trans-10, cis-12 conjugated linoleic acid reduces triglyceride content while differentially affecting peroxisome proliferator activated receptor gamma 2 and aP2 expression in 3T3-L1 preadipocytes. Lipids 36: 1223-1232.

Havel RJ, Eder HA, Bragdon JA (1955) The distribution and chemical composition of ultracentrifugally separated lipoproteins in human serum. J Clin Invest 34: 1345-1353.

Kliewer SA, Lehmann JM, Willson TM (1999) Orphan nuclear receptors: shifting endocrinology into reverse. Science 284: 757-760.

Lee KN, Kritchevsky D, Pariza MW (1994) Conjugated linoleic acid and atherosclerosis in rabbits. Atherosclerosis 108: 19-21.

Lee SH, Yamaguhi K, Kim JS, Eling TE (2006a) Conjugated linoleic acid stimulates an anti-tumorigenic protein NAG-1 in an isomer specific manner. Carcinogenesis 27: 972-981.

Lee SH, Yamaguhi K, Kim JS, Eling TE (2006b) Conjugated linoleic acid stimulates an anti-tumorigenic protein NAG-1 in an isomer specific manner. Carcinogenesis 27: 972-981.

Lee KW, Lee HJ, Cho HY, Kim YJ (2005) Role of the conjugated linoleic acid in the prevention of cancer. Crit Rev Food Sci Nutr 45: 135-144.

Nagy L, Tontonoz P, Alvarez JG, Chen H, Evans RM (1998) Oxidized LDL regulates macrophage gene expression through ligand activation of PPARgamma. Cell 93: 229-240.

Park SJ, Park CW, Kim SJ, Kim JK, Kim YR, Park KA, Kim JO, Ya YL (2002) Methylation methods for the quantitative analysis of conjugated linoleic acid (CLA) isomers in various lipid samples. J Agric Food Chem 50: 989-986.

Pietsch A, Weber C, Goretzki M, Weber PC, Lorenz RL (1995) N-3 but not N-6 fatty acids reduce the expression of combined adhesion and scavenger receptor CD36 in human monocytic cells. Cell Biochem Funct 13: 211-216.

Prieur X, Roszer T, Rocote M (2009) Lipotoxicity in macrophages: evidence from diseases associated with the metabolic syndrome. Biochim Biophys Acta doi.1016/j.bbalip.2009.09.017.

Rahman MM, Bhattacharya A, Fernandes GJ (2006) Conjugated linoleic acid inhibits osteoclast differentiation of RAW 264.7 cells by modulating RANKL signalling. Lipids Res 47: 1739-1748.

Ringseis R, Wen G, Saal D, Eder K (2008) Conjugated linoleic acid isomers reduce cholesterol accumulation in acetylated LDL-induced mouse RAW264.7 macrophage-derived foam cells. Lipids 43: 913923.

Stachowska E, Baśkiewicz-Masiuk M, Dziedziejko V, Adler G, Bober J, Machaliński B, Chlubek D (2007) Conjugated linoleic acids can change phagocythosis of human monocytes/macrophages by reduction in Cox-2 expression. Lipids 42: 707-716. 
Stachowska E, Baśkiewicz-Masiuk M, Dziedziejko V, Gutowska I, Baranowska-Bosiacka I, Marchlewicz M, Dołegowska B, Wiszniewska B, Machaliński B, Chlubek D (2008) Conjugated linoleic acid increases intracellular ROS synthesis and oxygenation of arachidonic acid in macrophages. Nutrition 24: 187-189.

Taketa K, Matsumura T, Yano M, Ishii N, Senokuchi T, Motoshima H, Murata Y, Kim-Mitsuyama S, Kawada T, Itabe H, Takeya M, Nishikawa T, Tsuruzoe K, Araki E (2008) Oxidized low density lipoprotein activates peroxisome proliferator-activated receptoralpha (PPAR alpha) and PPAR gamma through MAPK-dependent MAPK-dependent COX-2 expression in macrophages. I Biol Chem 283: 9852-9862.

Teupser D, Mueller MA, Koglin J, Wilfert W, Ernst J, von Scheidt W, Steinbeck G, Seidel D, Thiery J (2008) CD 36 mRNA expression in increased in CD14+ monocytes of patients with coronary heart disease. Clin Exp Pharmacol Physiol 35: 552-556.
Tontonoz P, Nagy L, Alvarez JG, Thomazy VA, Evans RM (1998) PPARgamma promotes monocyte/macrophage differentiation and uptake of oxidized LDL. Cell 93: 241-252.

Toomey S, Roche H, Fitzgerald D, Belton O (2003) Regression of preestablished atherosclerosis in the apoE $/$ mouse by conjugated linoleic acid. Biochem Soc Trans 31: 1075-1079.

Vallvé JC, Uliaque K, Girona J, Cabré A, Ribalta J, Heras M, Masana L (2002) Unsaturated fatty acids and their oxidation products stimulate gene CD36 expression in human macrophages. Atherosclerosis 164: 45-56.

Whigham LD, Cook EB, Stahl JL, Saban R, Bjorling DE, Pariza MW, Cook ME (2001) CLA reduces antigen-induced histamine and PGE(2) release from sensitized guinea pig tracheae. Am J Physiol Regul Integr Comp Physiol 280: R908-R912.

Xie S, Lee YF, Kim E, Chen LM, Ni J, Fang LY, Liu S, Lin SJ, Abe J, Berk B, Ho FM, Chang C (2009) TR4 nuclear functions as a fatty acid sensor to modulate CD36 expression and foam cell formation. Proc Natl Acad Sci USA 106: 13353-13358. 